\title{
PENGARUH PERSENTASE KUNING TELUR ITIK DAN ASAM FORMIAT DALAM PROSES PEMINYAKAN TERHADAP KEKUATAN FISIK KULIT KAKI AYAM PEDAGING SAMAK KHROM
}

\author{
Effect of Ducks Yolk and Formic Acid in Fat Liquoring Process on the Physical \\ Quality of Broiler Chicken Shank Chrome Tanning
}

\author{
Mustakim $^{1}$, Aris Sri Widati ${ }^{1}$, Khotibul Umam Al Awwaly ${ }^{1}$, Lita Umaya ${ }^{2)}$ \\ 1) Bagian Teknologi Hasil Ternak, Fakultas Peternakan, Universitas Brawijaya \\ 2) Mahasiswa Bagian Teknologi Hasil Ternak, Fakultas Peternakan, Universitas Brawijaya
}

Diterima 18 Agustus 2015; diterima pasca revisi 17 September 2015

Layak diterbitkan 1 Oktober 2015

\begin{abstract}
The purpose of this study was to find out the effect of ducks yolk and formic acid in fat liquoring process of the tanned skin. The materials used in this study were 30 pieces of 7 weeks of broiler chicken shank. The study was carried out using completely randomized design. The variables measured were softness, tensile strength and stretch of the tanned skin. Data were analyzed by analysis of variance and followed by Duncan's Multiple Range Test. The research results showed that the addition of ducks yolk and formic acid didn't gave significantly affect on the softness ( $p>0.05)$, while gave highly significant affect on tensile strength and stretch $(p<0.01)$. Interaction between two treatment didn't gave significantly affect $(p>0.05)$ on the softness and stretch, and have significantly $(p<0.05)$ on the tensile strength of leather. The conclusion of this research the addition of $11 \%$ duck yolk and $1 \%$ formic acid in fat liquoring is the best treatment for broiler chicken shank chrome tanning on the skin softness $(2,667)$, tensile strength $\left(135,707 \mathrm{~kg} / \mathrm{cm}^{2}\right)$, and stretch $(37,34 \%)$, respectively.
\end{abstract}

Key words: Broiler chicken shank, chrome tanning, ducks yolk, formic acid, and fat liquoring process

\section{PENDAHULUAN}

Kaki ayam merupakan bagian tubuh ayam yang kurang diminati, karena bagian ini selain tidak berdaging juga bersisik, sehingga kaki ayam lebih banyak dimanfaatkan untuk campuran dalam memasak sup dan untuk campuran pakan ternak. Kulit kaki ayam ini dapat dimanfaatkan kulitnya untuk disamak menjadi kerajinan, sehingga mempunyai nilai ekonomis yang tinggi. Menurut Purnomo (1992), kulit kaki ayam memiliki corak maupun warna yang bervariasi, bentuk relief bagian depan lebar-lebar dan kaki bagian belakang bergaris kecil-kecil.

Teknologi pengolahan kulit juga sangat menentukan keindahan dari kulit samak yang dihasilkan. Penentuan penyamakan terhadap kulit harus disesuaikan dengan jenis produk yang akan diolah (Lutfie dkk., 1990). Penyamakan bertujuan untuk mengubah kulit mentah yang mudah rusak oleh aktivitas mikroorganisme, reaksi kimia atau kerusakan fisik menjadi kulit tersamak yang lebih tahan terhadap pengaruh- 
pengaruh tersebut. Penyamakan kulit secara umum dibagi menjadi empat, yaitu penyamakan nabati, minyak, sintetis dan mineral.

Penyamakan kulit secara mineral dengan bahan penyamak krom paling banyak digunakan diantara bahan penyamak mineral lainnya. Hal ini disebabkan atom-atom khrom valensi $3^{+}$ mampu bereaksi dan membentuk ikatan dengan asam-asam amino dalam struktur protein kolagen yang reaktif (Purnomo, 1992). Kulit yang disamak dengan bahan penyamak khrom mempunyai beberapa kelebihan, diantaranya adalah kulit samaknya lebih lemas, tahan terhadap panas yang tinggi, kekuatan tariknya lebih tinggi dan hasilnya lebih baik bila dilakukan pengecatan. Proses peminyakan (fat liquoring) merupakan salah satu tahapan di dalam proses penyamakan kulit yang bertujuan untuk menjadikan kulit lebih lemas, lebih lunak, fleksibel, kemulurannya lebih tinggi dan lebih liat sesuai dengan standar yang telah ditentukan.

Kuning telur itik dapat digunakan sebagai salah satu alternatif bahan peminyakan dalam proses penyamakan kulit, karena kandungan lemaknya lebih tinggi daripada telur unggas lain. Kuning telur itik mengandung trigliserida dan asam lemak tak jenuh yang terdiri dari asam oleat $12,9 \%$ dan asam linoleat $2,9 \%$. Tingginya kandungan asam lemak tak jenuh dalam kuning telur itik menyebabkan kuning telur itik mudah teremulsi seperti halnya minyak komersial lainnya. Telur merupakan pengemulsi yang baik, karena adanya lecitoprotein, yang merupakan suatu kompleks yang terdiri dari lecitin dan protein (Winarno, 1992).

Proses fiksasi kulit dilakukan setelah proses peminyakan dengan tujuan untuk memecahkan emulsi minyak, sehingga minyak dapat tersebar merata dan berikatan dengan serat-serat kolagen kulit. Bahan yang digunakan untuk proses fiksasi kulit pada umumnya adalah asam formiat $(\mathrm{HCOOH})$, karena mudah didapatkan dan lebih efisien. Kulit samak jika tidak diminyaki akan menjadi kaku dan kekuatan tariknya lebih rendah (Nugroho, 1996).

Jenis dan jumlah minyak yang digunakan dalam proses peminyakan akan mempengaruhi tingkat kelemasan kulit. Oetojo (1997) menyatakan bahwa penggunaan kuning telur dan Polarassol SS dengan konsentrasi masing-masing 5\% dapat digunakan untuk proses peminyakan kulit kambing. Hasil penelitian Mustakim (1999) menyatakan bahwa kulit kaki ayam yang disamak khrom 2,5\% dengan menggunakan minyak Paradol $A G$ dan Paradol HISN 5\% menghasilkan kekuatan tarik sebesar $134,82 \mathrm{~kg} / \mathrm{cm}^{2}$. Kulit kaki ayam yang telah disamak dapat dijadikan barang kerajinan yang bernilai ekonomis tinggi berupa dompet maupun tali jam tangan. Berdasarkan uraian di atas maka perlu dilakukan penelitian mengenai pengaruh persentase kuning telur itik dan asam formiat dalam proses peminyakan terhadap kelemasan, kekuatan tarik dan kemuluran kulit kaki ayam samak khrom.

\section{MATERI DAN METODE}

30 lembar kulit kaki ayam segar umur 7 minggu. Telur itik dari Yogyakarta dengan umur simpan yang sama dan tidak lebih dari 1 minggu dan belum dilakukan perlakuan.

$\mathrm{CaOH}_{2}, \mathrm{Na}_{2} \mathrm{~S}, \mathrm{ZA}$, Asam sulfat, Teepol, Orophon, Asam formiat, Kromosal B, Natrium bikarbonat, Natrium Karbonat, Syntan, Cat dasar, Mimosa, Minyak sulphonasi, anti jamur, dan kasein.

Pisau, talenan, kaleng oli, alat stacking, rumah keong, ember plastic, drum putar, penjepit, papan pementang, timbangan digital elektrik Sartorius dengan kepekaan 0,01 gram, kertas $\mathrm{pH}$, Tensile strength tester merek KT-7010 D2, Nomor seri 7413 spesifikasi 220 Volt, 4kw dan kekuatan 
maksimal $500 \mathrm{~kg}$ untuk mengukur kekuatan tarik dan kemuluran kulit.

Metode penelitian yang digunkaan percobaan faktorial menggunakan rancangan acak lengkap (RAL), faktor pertama tingkat penggunaan kuning telur itik yaitu $6 \%$ (D1), 8,5\% (D2), dan $11 \%$ (D3). Faktor kedua penggunaan variasi asam formiat yaitu $0,75 \%$ (L1), $1 \%$ (L2), dan 1,25\% (L3). Kedua faktor tersebut akan menghasilkan 9 kombinasi dan masingmasing kombinasi diulang 3 kali. Kulit kaki ayam sebanyak 30 lembar dibagi menjadi dua bagian yang terdiri dari tigalembar kulit sebagai kontrol, dilakukan peminyakan dengan paradol HISN 5\%, kemudian difiksasi menggunakan asam formiat $1 \%$ dan 27 lembar kulit sebagai perlakuan yaitu peminyakan menggunakan kuning telur itik dan variasi asam formiat dalam proses fiksasi.

\section{Prosedur Penelitian}

Proses penyamakan terbagi atas tiga tahapan yaitu tahap awal penyamakan (beam house operation), penyamakan (tanning) dan penyelesaian (finishing). Proses penyamakan kulit kaki ayam pedaging dengan bahan peminyak kuning telur itik dan asam formiat untuk proses fiksasi adalah sebagai berikut:

1. Proses rumah basah (beam house operation)

Penimbangan (weighing)

Sampel kulit kaki ayam pedaging sebanyak 30 lembar disiapkan, kemudian ditimbang untuk mengetahui berat awal kulit yang kemudian dijadikan sebagai bahan dasar untuk perhitungan berat bahanbahan kimia yang dibutuhkan dalam proses selanjutnya.

\section{Pencucian (washing)}

Pencucian menggunakan air sebanyak $200 \%$ dan $1 \%$ teepol, kemudian diputar di dalam drum selama 30 menit, cairan perendaman dibuang dan dicuci menggunakan air mengalir selama 15 menit.

\section{Pengapuran (liming)}

Dilarutkan 3\% $\mathrm{Na}_{2} \mathrm{~S}$ dengan air panas (1:10), dilarutkan dalam $300 \%$ air, diputar dengan kecepatan 12 rpm selama 30 menit setiap jam (diulang 2 kali). $\mathrm{Ca}(\mathrm{OH})_{2}$ sebanyak $4 \%$ dan $0,5 \%$ teepol ditambahkan ke dalam drum, diputar selama 15 menit setiap 45 menit (diulang 4 kali), lalu direndam semalam. Kemudian diputar 10 menit dan dicuci dengan air mengalir selama 15 menit.

\section{Buang Daging (fleshing)}

Dilakukan penghamparan kulit diatas papan kayu. Kulit pada bagian daging mengahadap ke atas, kemudian dilakukan pengerokkan terhadap tenunan lemak menggunakan pisau seset. Kemudian kulit ditimbang. Hasil timbangan disebut dengan bloten. Proses selanjutnya, persentase penggunaan bahan-bahan kimia dihitung berdasarkan berat kulit bloten.

\section{Buang Kapur (deliming)}

Kulit dimasukkan ke dalam drum berisi air $200 \%$ dan ZA $1 \%$, diputar selama 30 menit, lalu ditambahkan $0,5 \%$ asam formiat dan diputar selama 30 menit. Penampang ditetesi dengan phenolptalin indikator menunjukkan warna putih.

Oropon sebanyak $1 \%$ ditambahkan ke dalam drum, diputar selama 30 menit. Kesempurnaan proses diuji dengan thumb test yaitu dengan menekan kulit menggunakan ibu jari, bila bekas tekanan lama kembali ke posisi semula maka dikatakan sempurna.

Penghilang lemak dilakukan dengan menambahkan $1 \%$ teepol, diputar selama 30 menit, lalu larutan dibuang dan kulit dicuci dengan air mengalir selama 15 menit. Proses dianggap sempurna bila kedua permukaan kulit terasa kesat dan tidak berminyak. 


\section{Pengasaman (pickling)}

Proses pengasaman dilakukan dengan memutar kulit dalam drum berisi $100 \%$ air dan $10 \%$ garam selama 10 menit, ditambahkan $0,5 \% \mathrm{HCOOH}(1: 10)$ dalam 2 kali penambahan berselang 10 menit. Asam sulfat $1 \%$ (1:10) ditambahkan ke dalam drum dalam 3 kali penambahan berselang 40 menit. Kesempurnaan proses uji dengan menetesi penampang kulit dengan BCG (Brom Cresol Green) indikator. Bila kulit berwarna kuning maka proses berlangsung sempurna. Pengecekan $\mathrm{pH}$ larutan yaitu antara 2-3,5. Kemudian direndam semalam dan esoknya diputar selama 15 menit, larutan dibuang.

\section{Penyamakan (tanning)}

Penyamakan (tanning)

Kulit diaduk selam 15 menit. Bahan yang digunakan adalah 100\% air pickle (air bekas pengasaman), ditambah $8 \%$ Chromosal B. drum yang telah berisi kulit dan larutan penyamak diputar selama 120 menit. Ditambahkan $1,5 \%$ natrium bikarbonat $\left(\mathrm{NaHCO}_{3}\right)$ yang diencerkan dengan air (1:10) dan ditambahkan dalam 3 tahap dengan selang waktu 15 menit, kemudian dicek pH larutan 3,8-4. Pengujian proses penyamakan dilakukan dengan boiling test yaitu dengan merebus potongan kulit yang tebal dalam air mendidih selama 10 menit. Apabila pengerutan kurang dari $10 \%$ dari potongan semula, maka penyamakan telah selesai dengan baik. Kulit yang telah mengalami proses penyamakan disebut dengan kulit wet blue. Kulit wet blue diperam (aging) selama 1 malam dengan cara diangin-anginkan. Berat kulit wet blue ini dijadikan dasar dalam pengukuran berat bahan-bahan kimia yang digunakan dalam proses finishing.

\section{Penyelesaian (Finishing)}

\section{Netralisasi}

Proses netralisasi ini dilakukan dengan memutar kulit selama 15 menit dalam larutan 200\% air dan 0,5\% natrium formiat, kemudian dilanjutkan dengan penambahan $0,5 \% \mathrm{NaHCO}_{3}$ dan diputar kembali selama 15 menit. Proses dinyatakan sempurna apabila $\mathrm{pH}$ kulit mencapai 5,5-6. Kulit kemudian dicuci bersih dengan air mengalir selama 15 menit.

\section{Penyamakan Ulang (retanning)}

Bahan-bahan yang digunakan adalah air $200 \%$ dan bahan penyamak sintesis (Syntan) 2\%, diputar dalam drum selama 30 menit, lalu dibersihkan dengan air mengalir.

Pengecatan Dasar (Dyeing)

Proses pengecatan dasar ini menggunakan air hangat $\left(50^{\circ} \mathrm{C}\right)$ sebanyak $150 \%$ dan $0,5 \%$ amoniak, diputar selama 10 menit, kemudian ditambahkan $0,5 \%$ cat dasar, lalu diputar selama 60 menit. Kulit kemudian diperam sampai air tidak menetes lagi.

\section{Peminyakan (fat liquoring)}

Formula untuk proses peminyakan adalah air $50 \%$ degan suhu $60^{\circ} \mathrm{C}$ dan kuning telur itik $6 \%, 8,5 \%$ dan $11 \%$, untuk kontrol menggunakan $5 \%$ minyak sulfat, kemudian dimasukkan ke dalam drum dan diputar selama 60 menit.

\section{Fiksasi (fisation)}

$0,75 \%, 1 \%$ dan $1,25 \%$ asam formiat ( $\mathrm{HCOOH})$ ditambahkan ke dalam drum, diputar selama 20 menit sampai cairan bening.

\section{Pengeringan (drying)}

Kulit kaki ayam yang dianginanginkan selama 6 jam

\section{Pelemasan}

Kulit kaki ayam yang sudah kering kemudian dilemaskan dengan alat stool.

\section{Pelapisan}

20 gram casein dilarutkan dalam $60 \mathrm{ml}$ air $\left(60^{\circ} \mathrm{C}\right)$, kemudian dioleskan pada bagian rajah kulit, selanjutnya kulit dikeringkan 
(dijemur). Kegiatan ini diulang sebanyak 2 kali.

\section{Glazing}

Bagian rajah kulit digosok dengan menggunakan rumah keong hingga mengkilap

\section{Embossing}

Kulit disetrika menggunakan embossing machine dengan suhu $90^{\circ} \mathrm{C}$ bertekanan 100 barr selama 2 detik.

Pengujian sampel kulit kaki ayam samak khrom

1. Pengukuran kelemasan dengan cara menilai kulit berdasarkan uji organoleptik yang dilakukan oleh 5 panelis terlatih menurut Nugroho (1996)

2. Pengukuran kekuatan tarik dan kemuluran kulit menurut Anonimous (1989)

\section{Analisis Data}

Data yang diperoleh dianalisis secara statistik dengan menggunakan analisis sidik ragam dan apabila rata-rata perlakuan terdapat perbedaan maka analisis data dilanjutkan dengan menggunakan Uji Jarak berganda Duncan.

\section{HASIL DAN PEMBAHASAN}

\section{Kelemasan Kulit}

Hasil analisis ragam uji kelemasan kulit menunjukkan bahwa tingkat persentase kuning telur itik maupun asam formiat yang ditambahkan pada proses peminyakan berpengaruh tidak nyata $(\mathrm{P}>0,05)$ terhadap kelemasan kulit samak. Interaksi kedua perlakuan tidak berbeda nyata $(\mathrm{P}>0,05)$ terhadap kelemasan kulit. Hasil rata-rata kelemasan kulit disajikan pada Tabel 1.

Tabel 1. Rata- rata Skor Uji Kelemasan Kulit Kaki Ayam Samak Khrom dengan Perlakuan Persentase Kuning Telur Itik dan Asam Formiat.

\begin{tabular}{ccccc}
\hline Kuning Telur (D) & \multicolumn{3}{c}{ Asam Formiat (L) } & Rata-rata \\
\cline { 2 - 4 } & L1 $(0,75 \%)$ & L2 $(1,0 \%)$ & L3 $(1,25 \%)$ & \\
\hline D1 $(6,0 \%)$ & 2,800 & 2,467 & 2,600 & $2,622 \pm 4,072$ \\
D2 $(8,5 \%)$ & 2,600 & 2,993 & 2,733 & $2,755 \pm 4,178$ \\
D3 (11\%) & 2,800 & 2,667 & 2,993 & $2,800 \pm 4,296$ \\
\hline Rata-rata & $2,733 \pm 4,183$ & $2,689 \pm 4,124$ & $2,755 \pm 4,245$ & \\
\hline
\end{tabular}

Berdasarkan data dalam Tabel 1 nilai kelemasan kulit tertinggi dicapai pada perlakuan D2L2 dan D3L3 sebesar 2,993 dan nilai kelemasan terendah pada perlakuan D1L2 sebesar 2,467. Data dalam Tabel 1 menunjukkan bahwa rata-rata kelemasan kulit tidak berbeda nyata pada semua perlakuan. Hal ini menunjukkan bahwa persentase kuning telur itik yang ditambahkan pada proses peminyakan serta asam formiat pada proses fiksasi kulit memberikan hasil yang hampir sama terhadap tingkat kelemasannya, dikarenakan kuning telur itik dapat teremulsikan dengan baik dan dapat menyebar secara merata ke dalam seratserat kolagen kulit, menjadikan serat kolagen tidak lengket satu sama lainnya sehingga kulit lebih lemas. Tuck (1983) menyatakan bahwa jumlah minyak yang digunakan berpengaruh terhadap kelemasan kulit. Air digunakan sebagai media penghubung dalam bentuk emulsi dengan maksud agar minyak tidak hanya tersebar dipermukaan saja tetapi mampu menetrasikan ke dalam serat kulit.

Jumlah minyak yang digunakan pada proses peminyakan disesuaikan dengan tujuan akhir kulit serta tingkat kelemasan 
yang ingin dicapai. Kulit yang digunakan sebagai bahan baku pembuatan tas, ikat pinggang, dompet maupun sepatu tidak memerlukan tingkat kelemasan yang tinggi, lain halnya dengan kulit yang dijadikan bahan baku pembuatan jaket maka kulit yang digunakan mempunyai tingkat kelemasan yang tinggi.

Masuknya minyak ke dalam serat-serat kulit adalah sebagai pelican sehingga seratserat kulit lebih bebas digerakkan. Minyak yang sudah masuk ke dalam serat-serat kulit lebih bebas digerakkan. Minyak yang sudah masuk ke dalam serat-serat kolagen kulit dalam kondisi yang stabil karena emulsi minyak terpecah oleh $\mathrm{HCOOH}$ pada waktu fiksasi, sehingga lemak akan tertinggal dan air dilepaskan (Thorstensen, 1985).

\section{Kekuatan Tarik Kulit}

Hasil analisis ragam uji kekuatan Tarik kulit menunjukkan bahwa tingkat persentase kuning telur itik dan asam formiat yang ditambahkan pada proses peminyakkan berpengaruh sangat nyata $(\mathrm{P}<0,01)$ terhadap kekuatan tarik kulit. Interaksi antara kedua perlakuan memberikan pengaruh yang nyata $(\mathrm{P}<0,05)$ terhadap kekuatan tarik kulit.

Kekuatan tarik kulit tertinggi dicapai pada perlakuan D3L2 sebesar 135,707 $\mathrm{kg} / \mathrm{cm}^{3}$ dan kekuatan tarik terendah pada perlakuan D1L1 sebesar 100,760 kg/ $\mathrm{cm}^{3}$. Hasil rata-rata kekuatan tarik dan uji jarak berganda Duncan 1\% selengkapnya dapat dilihat pada Tabel 2.

Tabel 2. Rata-Rata Uji Kekuatan Tarik Kulit $\left(\mathrm{kg} / \mathrm{cm}^{3}\right)$ Kaki Ayam Samak Khrom dengan Perlakuan Persentase Kuning Telur Itik dan Asam Formiat.

\begin{tabular}{ccccc}
\hline Kuning Telur & \multicolumn{3}{c}{ Asam Formiat (L) } & Rata-Rata \\
\cline { 2 - 4 }$(\mathrm{D})$ & $\mathrm{L} 1(0,75 \%)$ & $\mathrm{L} 2(1,0 \%)$ & $\mathrm{L} 3(1,25 \%)$ & \\
\hline D1 $(6,0 \%)$ & 100,760 & 104,457 & 111,400 & $105,539^{\mathrm{A}} \pm 5,133$ \\
D2 $(8,5 \%)$ & 117,960 & 120,540 & 128,360 & $122,287^{\mathrm{B}} \pm 5,162$ \\
D3 (11\%) & 131,710 & 135,707 & 135,267 & $134,228^{\mathrm{C}} \pm 2,943$ \\
\hline Rata-Rata & $116,810^{\mathrm{a}} \pm 13,564$ & $120,235^{\mathrm{b}} \pm 13,713$ & $125,009^{\mathrm{c}} \pm 10,898$ & \\
\hline
\end{tabular}

Keterangan: Notasi yang berbeda menunjukkan ada perbedaan yang sangat nyata $(\mathrm{P}<0,01)$

Data dalam Tabel 2 menunjukkan bahwa rata-rata kekuatan tarik kulit meningkat dengan meningkatnya persentase kuning telur itik dan asam formiat yang ditambahkan pada proses peminyakan. Kekuatan tarik tertinggi diperoleh pada kulit kaki ayam yang diberi perlakuan kuning telur itik sebesar $6 \%$ dan $8,5 \%$ dengan variasi asam formiat $0,75 \%$, $1,0 \%$ dan $1,25 \%$ adalah lebih kecil dari kontrol, sedangkan perlakuan kuning telur $11 \%$ lebih besar dari kontrol. Perlakuan kuning telur $11 \%$ dapat digunakan sebagai bahan peminyakan untuk menggantikan minyak komersil yaitu paradol HISN, dikarenakan kandungan lemaknya hampir asam dengan kuning telur itik yang terdiri dari asam oleat, asam linoleat dan asam linolenat. Perlakuan asam formiat $0,75 \%$ sudah dapat digunakan untuk proses fiksasi kulit yang dimaksudkan untuk memecahkan emulsi minyak yang terdapat dalam kulit.

Stadelman and cotteril (1977), menyatakan bahwa penggunaan bahan pengemulsi yang berlebihan akan menyebabkan terbentuknya kristal-kristal bahan pengemulsi yang mengurangi kelarutan dan kemampuan dalam pembentukan sistem emulsi antara minyak dan air.

Tinggi rendahnya kekuatan tarik dipengaruhi oleh tebal kulit, kandungan protein kolagen dan tebal koranium (Sastrodiharjo, 1990) Soeramto (1993) lebih lanjut menyatakan bahwa sifat-sifat fisik kulit juga dipengaruhi oleh struktur jaringan kulit, yaitu berkas-berkas kolagen 
(98\% dari total serabut kulit) yang tersusun atas serabut-serabut kolagen yang saling beranyaman membentuk seperti jala. Sudut yang dibentuk oleh anyaman dan kepadatan berkas kolagen inilah yang menentukan tinggi rendahnya kekuatan tarik, pada sudut anyaman kurang dari $45^{\circ}$ maka kulit samak akan mempunyai kekuatan tarik yang tinggi dan sebaliknya apabila sudut yang dibentuk oleh serabut kolagen lebih dari $45^{\circ}$ maka kekuatan tarik yang dihasilkan semakin rendah. Lanning (1996) lebih lanjut menyatakan bahwa pada sudut serabut kolagen yang kecil akan menghasilkan kulit samak yang kuat dan kurang elastis, namun lebih lembut jika dibandingkan dengan kulit samak yang mempunyai sudut serabut kolagen lebih besar.

Penggunaan minyak dapat mempengaruhi sifat-sifat fisik kulit, yaitu dapat menambah kekuatan tarik kulit (Sarkar, 1995). Minyak dan lemak menyebabkan kulit menjadi lemas, berisi, lembut, lentur dan menambah kekuatan tarik serta kemuluran dan kehalusan rajah. Khemikalia yang digunakan untuk proses peminyakan adalah minyak yang dapat teremulsi.

Lemak kuning telur itik terdiri dari trigliserida, phospolilipd dan kolesterol. Lemak sebagian besar bergabung dengan protein membentuk senyawa lipoprotein, yang di dalamnya terkandung lecitin. Lecitin mempunyai bagian yang larut dalam minyak dan bagian yang mengandung $\mathrm{PO}_{4}{ }^{3-}$ (polar) yang larut dalam air sehingga lecitin kuning telur dapat digunakan sebagai emulsifier. Daya emulsifier yang kuat dari kuning telur karena kandungan lecitinnya yang terdapat dalam bentuk kompleks sebagai lecithin-protein.

Daya kerja lecitin kuning telur sebagai emulsifier disebabkan oleh bentuk molekulnya yang dapat terikat bak pada minyak maupun air. Gugus polar dari lecitin cenderung larut dalam air (hidrofilik), sedangkan gugus non polar pada ester-ester asam lemaknya cenderung larut dalam minyak (lipofilik) sehingga mengurangi tegangan permukaan (surface tension) antara molekul minyak dan molekul air dan terbentuklah emulsi yang stabil. Semakin tinggi konsentrasi kuning telur itik yang ditambahkan sebagai bahan dalam proses peminyakan akan memingkatkan jumlah globula lemak atau minyak dalam air, diharapkan minyak mampu terpenetrasi secara sempurna dan tersebar merata ke dalam serat-serat kulit. Keadaan ini ditandai dengan keluarnya cairan tidak berwarna dan bening setelah proses peminyakan berakhir. Fiksasi kulit dengan asam formiat (HCOOH) bertujuan untuk memecahkan emulsi minyak, sehingga lemak akan tertinggal dan tetap berikatan denga serat kulit sedangkan air dilepaskan.

Pelaksanaan proses peminyakan juga dipengaruhi oleh netralisasi dan pengecatan dasar. Kulit yang disamak dengan penyamak khrom akan bersifat asam $(\mathrm{pH}$ 3,8-4,0). Asam-asam yang terikat diantara serat-serat kulit maupun asam bebas yang tidak hilang pada waktu pencucian perlu dinetralisir agar emulsi minyak bisa meresap ke dalam penampang kulit dan pada pengecatan dasar cat yang terikat pada permukaan kulit menjadi rata.

Hasil pengujian kekuatan tarik kulit kaki ayam samak khrom dengan perlakuan kuning telur itik sebagai bahan perminyakan dan asam formiat dalam proses fiksasi kulit mempunyai rata-rata kekuatan Tarik di bawah tandar SNI untuk kulit glaze, yaitu sebesar $150 \mathrm{~kg} / \mathrm{cm}^{2}$. Hal ini disebabkan kulit kaki ayam mempunyai ketebalan yang tidak seragam yaitu dibagian rajahnya terdapat motif berupa sisik, sehingga kulit samak kaki ayam lebih menonjolkan keindahan rajahnya.

\section{Kemuluran Kulit}

Hasil analisis ragam uji kemuluran kulit memnunjukkan bahwa tingkat persentase kuning telur itik berpengaruh sangat nyata $(\mathrm{P}<0,01)$ dan tingkat persentase asam formiat memberikan 
pengaruh yang nyata $(\mathrm{P}<0,05)$, tidak ada interaksi antara penambahan kuning telur itik dan asam formiat terhadap kemuluran kulit.

Kemuluran kulit tertinggi dicapai pada perlakuan D3L2 sebesar $37,34 \%$ dan kemuluran terndah pada perlakuan D1L2 sebesar $26,74 \%$. Hasil rata-rata kemuluran dan uji jarak berganda Duncan 1\% selengkapnya dapat dilihat pada Tabel 3 .

Tabel 3. Rata-Rata Uji Kemuluran Kulit (\%) Kaki Ayam Samak Khrom dengan Perlakuan Perentase Kuning Telur Itik dan Asam Formiat.

\begin{tabular}{ccccc}
\hline $\begin{array}{c}\text { Kuning Telur } \\
(\mathrm{D})\end{array}$ & L1 $(0,75 \%)$ & $\begin{array}{c}\text { Asam Formiat (L) } \\
\text { L2 }(1,0 \%)\end{array}$ & L3 $(1,25 \%)$ & Rata-rata \\
\hline D1 (6,0\%) & 27,22 & 26,74 & 29,71 & $27,89^{\mathrm{a}} \pm 2,216$ \\
D2 (8,5\%) & 30,39 & 32,57 & 33,88 & $32,28^{\mathrm{b}} \pm 2,297$ \\
D3 (11\%) & 35,07 & 37,34 & 36,31 & $36,24^{\mathrm{c}} \pm 1,667$ \\
\hline
\end{tabular}

Rata-rata $\quad 30,839^{\mathrm{a}} \pm 3,824 \quad 32,217^{\mathrm{b}} \pm 4,794 \quad 33,30^{\mathrm{c}} \pm 3,227$

Keterangan: notasi yang berbeda menunjukkan ada perbedaan yang sangat nyata $(\mathrm{P}<0,01)$

Data pada Tabel 3 menunjukkan bahwa rata-rata kemuluran kulir kaki ayam yang diberi perlakuan kuning telur itik $6 \%$ dengan variasi asam formiat $0,75 \%, 1,0 \%$ dan $1,25 \%$ serta kuning telur itik $8,5 \%$ dengan variasi asam formiat $0,75 \%$ adalah lebih kecil dari kontrol, sedangkan perlakuan kuning telur $8,5 \%$ dan variasi asam formiat $1 \%$ dan $1,25 \%$ lebih besar dari kontrol. Perbedaan hasil pada semua perlakuan dikarenakan oleh perbedaan persentase kuning telur itik yang digunakan dan proses peminyakan. Sarkar (1995) menyatakan bahwa penggunaan minyak dapat mempengaruhi sifat-sifat fisik kulit samak. Penggunaan jenis dan besarnya minyak untuk proses peminyakan harus disesuaikan dengan jenis kulit jadi yang dihasilkan.

Rata-rata hasil kemuluran kulit kaki ayam samak khrom meningkat seiring dengan meningkatnya persentase kuning telur itik yang ditambahkan. Peningkatan persentase kuning telur itik akan meningkatkan bahan pengemulsi dalam serat-serat kolagen kulit sehingga globulaglobula lemak dapat terdispersi secara sempurna dalam fase cair, hal inilah yang meningkatkan kemuluran kulit.
Struktur jaringan kulit juga berpengaruh terhadap kemuluran, menurut Kanagy (1977), susunan serabut kolagen horizontal memiliki anyaman lebih jarang sehingga kulit lebih lunak dan menghasilkan kemuluran yang tinggi.

Tinggi rendahnya nilai kemuluran kulit juga dipengaruhi oleh proses netralisasi. Kulit samak khrom selama dalam keadaan basah akan selalu menghasilkan reaksi hidrolisa pada garam khrom sulfat basa yang selalu diikuti terbentuknya asam bebas di dalam kulit khrom basah. Adanya asam bebas akan mengahalangi masuknya kuning telur itik ke dalam kulit sehingga asam bebas harus dihilangkan dengan proses netralisasi, diharapkan emulsi minyak dari kuning telur dapat terpenetrasi ke dalam serat-serat kulit.

Hasil pengujian kemuluran kulit kaki ayam samak khrom dengan perlakuan kuning telur itik sebagai bahan peminyakan dan asam formiat dalam proses fiksasi kulit mempunyai rata-rata kemuluran di bawah $50 \%$. Kemuluran tersebut berrarti di bawah batas maksimal SNI untuk kulit glaze kambing/domba yaitu dengan batas maksimal 50\%, sehingga kulit kaki ayam samak khrom tersebut sudah bisa digunakan sebagai bahan industri perkulitan. 


\section{Penentuan Perlakuan Terbaik}

Penentuan perlakuan terbaik pada kulit kaki ayam samak khrom dengan penambahan kuning telur itik sebagai bahan peminyakan dan asam formiat sebagai bahan fiksasi kulit dillakukan dengan menggunakan indeks efektifitas (De Garmo, Sullivan and Canada, 1984).

Kulit kaki ayam samak khrom dengan perlakuan penambahan kuning telur itik sebagai bahan peminyakan dan asam formiat dala fiksasi kulit memberikan nilai terbaik pada D3L2, dengan nilai 0,942. Hasil perhitungan menunjukkan bahwa penggunaan kuning telur itik sebanyak $11 \%$ dan asam formiat sebanyak $1 \%$ merupakan perlakuan yang paling efektif dalam proses peminyakan kulit kaki ayam samak khrom.

\section{KESIMPULAN}

Kesimpulan dari penelitian ini adalah:

1. Persentase kuning telur itik dan asam formiat dalam proses peminyakan berpengaruh terhadap kekuatan tarik dan kemuluran kulit, tetapi tidak berpengaruh terhadap kelemasan kulit kaki ayam samak khrom.

2. Interaksi dari kuning telur itik dan asam formiat berpengaruh terhadap kekuatan tarik dan tidak berpengaruh terhadap kemuluran dan kelemasan kulit kaki ayam samak khrom.

3. Penggunaan kuning telur itik $11 \%$ dan asam formiat $1 \%$ dalam proses peminyakan memberikan hasil terbaik terhadap kelemasan, kekuatan tarik dan kemuluran kulit kaki ayam samak khrom degan nilai masing-masing sebesar 2,667 (lemas), $\quad 135,707 \quad \mathrm{~kg} / \mathrm{cm}^{2} \quad$ dan $37,34 \%$.

\section{DAFTAR PUSTAKA}

Anonimous. 1989. Pedoman Pengawetan Kulit Mentah. Kanisius. Yogyakarta.

Anonymous. 1989. Mutu dan Cara Uji Kulit Glace Kambing. SNI No. 0253-89-A

De Garmo, E.P., W.G. Sullivan and C.R Canada. 1984. Engineering Economy. Sevent edition. M. C Millan Publishing Company. New York.

Kanagy, J.R. 1977. Physical and Performance Properties of Leather. In: the Chemistry and Technology of Leather. Vol. 4. Ed. By Fred O'Flaherty, F., W.T. Roody and R.H Lollar. Krieger Publishing Company. Florida.

Lanning, D. 1996. The Manufacture of Leather Part 2. Skin Deep Newslatter J. Hewit and Sons. Ltd. www.hewit.com

Mustakim. 1999. Sifat-sifat Fisik dan Kimia serta Evaluasi Mutu Kulit Kaki Ayam Pedaging, Buras dan Ayam Petelur Afkir yang Disamak dengan Khrom. Thesis. Program Pasca Sarjana Universitas Gajah Mada. Yogyakarta.

Nugroho, S. 1996. Pengaruh Rasio Tawas dan Garam Dapur terhadap Kelemasan, Kekuatan Tarik dan Kemuluran Kulit Kaki Ayam Pedaging. Fakultas Peternakan Universitas Brawijaya. Malang.

Oetojo, B. 1997. Pengaruh Penggunaan Kuning Telur dan Polarassol SS Terhadap Kemuluran Kulit Krass Kambing. Majalah BBKP. Vol. XII No. 25. Yogyakarta.

Lutfie, M., Rahayu, E., Sulistyono, I., Suseno, A., Bazar, M., Indriyani, S., Andari D. 1990. Pengaruh Bahan Penyamak Terhadap Kekuatan Tarik Kelit Kaki (Shank) Ayam. Proceedings Seminar Sehari HAKTKI. Yogyakarta. 
Purnomo, E. 1992 Penyamakan Kulit Reptile. Kanisius. Yogyakarta.

Sarkar, K.T. 1995. Theory and Practise of Leather Manufacture. A.M Syarif 555 Poonamale High Road. Madras.

Sastrodiharjo, S. 1990. Kualitas Fisik Bagian Kroupon, Bahu dan Perut pada Kulit Mentah Kering Kelinci Rex Jantan. Seminar Sehari HAKTKI. BBKKP. Yogyakarta.

Stadelman, W.J. and D.J. Cotterill. 1977. Egg Science and Technology. The Avi Publishing Company Inc. New York.

Soeramto, Pertiwi, S., Widhiati. 1993. Pengaruh Perbedaan Lama Pengawetan dengan Garam Terhhadap Kekuatan Tarik dan Kemuluran Kulit Kaki Ayam Pedaging Samak Khrom. Symposium Nasional Perkulitan. BBKKP. Yogyakarta.

Thorstenten, T.C. 1985. Practical Leather Technology. Robert E. Krieger Publishing Company. New York.

Tuck, D.H. 1983. Oils and Lubricants Used on Leather. The Leather Conversation Centre. Northampton. England.

Winarno. F.G. 1992. Kimia Pangan dan Gizi. PT. Gramedia Pustaka Utama. Jakarta. 